\title{
Upaya Meningkatkan Kemampuan Membaca Permulaan Kelas 1 SD/MI dengan Metode Iqro di Madrasah Ibtidaiyah Al Hikmah Purwodadi Belitang Mulya OKU Timur
}

\author{
Sri Enggar Kencana Dewi ${ }^{1}$ Ratih Purnama Pertiwi ${ }^{2}$ \\ 1,2 STKIP Nurul Huda Sukaraja \\ E-mail: ${ }^{1}$ enggar@stkipnurulhuda.ac.id
}

INFOARTIKEL

Available online

DOI:

https://journal.stkipnurulhuda.ac.id/ index.php/JIMi/article/view/427

\section{How to cite (APA):}

Dewi, S. E., \& Pertiwi, R. (2019). Upaya Meningkatkan Kemampuan Membaca Permulaan Kelas 1 SD/MI dengan Metode laro di Madrasah Ibtidaiyah Al Hikmah Purwodadi Belitang Mulya OKU Timur. Jurnal Indonesia Mengabdi, 1(1), 11-15.

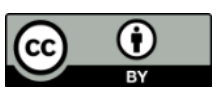

This work is licensed under a Creative Commons Attribution 4.0 International License

\section{ABSTRAK}

\section{Abstrak}

Salah satu tujuan untuk memberikan pembelajaran membaca permulaan pada anak SD/MI di kelas rendah yakni kelas 1, 2 dan 3 . Proses pembelajaran khususnya membaca pada MI Al-Hikmah Purwodadi, yang masih menggunakan cara manual yakni dengan cara mengeja dengan huruf yang sudah dikenal siswa membuat siswa sedikit kebingungan karena belum begitu paham dengan huruf abjad. Kebanyakan siswa Al-Hikmah Purwodadi kebanyakan ngaji di TPA sehingga siswa tersebut lebih paham huruf hijaiyah dibanding huruf abjad. Banyak siswa menghadapi kesulitan untuk membaca permulaan karena latar belakang siswa yang bukan dari lulusan TK. Sebagai solusi untuk memberikan kemudahan bagi siswa yang membaca permulaan dan bagi guru Ml Al-Hikmah Purwodadi untuk mempermudah proses pembelajaran dengan menggunakan metode dan media yang membuat termotivasi dan menarik untuk belajar membaca permulaan. Pada pengabdian ini metode yang digunakan adalah metode iqra. Hasil dan manfaat dari pengabdian yaitu meningkatnya minat baca pada siswa MI Al Hikmah Purwodadi, meningkatnya pengetahuan dan pemahaman siswa kelas $1 \mathrm{Ml}$ Al-Hikmah Purwodadi dalam membaca, meningkatnya keterampilan membaca pada siswa kelas $1 \mathrm{Ml}$ Al-Hikmah Purwodadi.

Kata kunci: Membaca Permulaan, Metode lqra

\section{Abstract}

One of the goals is to provide early reading learning for elementary / MI children in the lower classes, namely classes 1,2 and 3. The learning process especially reads at $\mathrm{MI}$ Al-Hikmah Purwodadi, who still uses the manual method by spelling with letters that students already know making students a little confused because they don't really understand the letters of the alphabet. Most of the students of Al-Hikmah Purwodadi were mostly recited at the TPA so that the students understood the hijaiyah letters more than the letters of the alphabet. Many students face difficulties in reading the beginning because of the background of students who are not from kindergarten graduates. As a solution to provide convenience for students who read the beginning and for $\mathrm{MI}$ Al-Hikmah Purwodadi teachers to simplify the learning process by using motivational and interesting methods and media to learn to read the beginning. In this service the method used is the iqra method. The results and benefits of service are increasing reading interest in $\mathrm{Ml} \mathrm{Al} \mathrm{Hikmah} \mathrm{Purwodadi} \mathrm{students,} \mathrm{increasing} \mathrm{knowledge} \mathrm{and}$ understanding of 1 st grade students of $\mathrm{MI}$ Al-Hikmah Purwodadi in reading, increasing reading skills in class $1 \mathrm{MI}$ Al-Hikmah Purwodadi.

Keywords: Reading Beginning, lqra Method 


\section{PENDAHULUAN}

Mata pelajaran bahasa Indonesia sudah diajarkan sedini mungkin dari prasekolah hingga perguruan tinggi dengan berbagai standar kompetensi dan kompetensi dasar yang berbeda, sehingga tidak heran jika peserta didik mahir berbahasa Indonesia. Hal ini tidak dapat dipungkiri bahwa kemahiran berbahasa Indonesia peserta didik dapat di mulai dari belajar membaca. Peserta didik tidak akan pernah bisa menulis, berbicara, memahami, menyimak dan menyampaikan pesan jika peserta tidak bisa membaca.

Membaca merupakan salah satu jenis kemampuan berbahasa tulis yang bersifat reseptif. Disebut reseptif karena dengan membaca seseorang akan mempeoleh informasi, ilmu pengetahuan dan pengalaman-pengalaman baru. Semua yang diperoleh melalui bacaan itu akan memungkinkan orang tersebut mampu mempertinggi daya pikirannya, mempertajam pandangannya, dan memperluas wawasannya. Oleh karena itu, pembelajaran membaca, guru dapat memilih wacana-wacana yang berkaitan dengan tokoh nasional, kepahlawanan, kenusantaraan, dan kepariwisataan. Selain itu melalui contoh pembelajaran membaca, guru dapat mengembangkan nilai-nilai moral, kemampuan bernalar dan kreativitas anak.

Membaca sangat memegang peranan penting dalam proses pembelajaran, karena pada setiap bidang studi tidak terlepas dari keterampilan membaca untuk dapat memperoleh wawasan dan pengetahuan karna guru dalam menyampaikan pembelajaran tidak mungkin selalu secara lisan di dalam kelas. Menurut (Lado dalam Henry Guntur Tarigan, 2008: 9) mengatakan bahwa membaca ialah memahami pola-pola bahasa dari gambar tertulisnya. sedangkan tujuan membaca menurut Henry Guntur Tarigan (2008: 9) bahwa tujuan utama dalam membaca adalah untuk mencari serta memperoleh informasi, mencakup isi, memahami makna bacaan.Membaca menurut Susanto (2011: 84) adalah menerjemahkan simbol (huruf) ke dalam suara yang dikombinasikan dengan kata-kata. kata-kata itu disusun sehingga kita dapat belajar memahaminya dan dapat membaca catatan.

Membaca permulaan menurut Slamet (2008: 58) mempunyai kedudukan yang sangat penting, keterampilan membaca permulaan akan sangat berpengaruh terhadap keterampilan membaca selanjutnya. Sebagai keterampilan yang mendasari keterampilan berikutnya maka keterampilan membaca permulaan benar-benar memerlukan perhatian guru, sebab jika dasar itu tidak kuat, pada tahap membaca permulaan anak akan mengalami kesulitan untuk dapat memiliki keterampilan membaca permulaan yang memadai.

Keterampilan membaca dalam mata pelajaran Bahasa Indonesia merupakan salah satu keterampilan dasar berbahasa yang berbahasa yang diajarkan di sekolah. Pengajaran membaca haruslah berisi usaha-usaha yang dapat membawa serangkaian keterampilan. Keterangan tersebut erat hubungannya dengan proses-proses yang mendasari pikiran semakin terampil seseorang berbahasa semakin cerdas dan jelas pula jalan pikirannya.

Keadaan yang terjadi lapangan menunjukkan bahwa dalam proses belajar membaca permulaan dilakukan dengan cara anak disuruh membaca huruf yang ditulis guru di papan tulis dan tidak menggunakan media-media. Perlu kita ketahui bahwa karakteristik materi tahap membaca awal yaitu pendek dan dapat diperkirakan, berulang-ulang, menggunakan bahasa yang sederhana, menggunakan irama, teksnya sederhana, mudah diingat, gambar dan teks sesuai, serta gambar sangat dominan. (Laely, 2013: 3)

Seperti yang diungkapkan oleh Kristian (dalam Fuad: 2009) "metode pembelajaran merupakan salah satu faktor yang menentukan keberhasilan suatu program", Sedangkan menurut Bakkidu (dalam Fuad: 2009) "metode pembelajaran merupakan komponen penentu utama kualitas pembelajaran, demikian pentingnya metode pembelajaran, sehingga harus dipilih dengan sebaik-baiknya". Metodologi mengajar dalam dunia pendidikan perlu dimiliki oleh pendidik, karena keberhasilan Proses Belajar Mengajar (PBM) bergantung pada cara mengajar gurunya. (Himmah, et al. 2016)

Metode Iqra' merupakan suatu metode yang menekankan langsung pada latihan membaca. Metode ini termasuk salah satu metode yang cukup terkenal dikalangan lembaga pendidikan dan 
masyarakat karena metode ini sudah umum dalam penggunaannya. Proses pembelajaran menggunakan metode iqra ini ada dengan guru memberikan contoh bacaan yang benar kemudian siswa mengikuti bacaan tersebut. Selain itu, guru juga harus menggunakan ucapan yang jelas dan komunikatif.

Berdasarkan uraian latar belakang di atas menjelaskan bahwa sangat penting sekali peningkatan membaca permulaan karena dengan membaca siswa pada sebuah lembaga pendidikan akan dapat menjadi siswa yang cerdas, akan banyak mendapatkan informasi lebih banyak. Dengan demikian penulis tertarik mengadakan pengabdian masyarakat di suatu lembaga pendidikan yaitu MI kelas 1 dalam upaya meningkatkan kemampuan membaca permulaan dengan metode iqra di MI Al-Hikmah Purwodadi Belitang Mulya.

\section{SOLUSI METODE}

Solusi dari pengabdian kepada masyarakat ini adalah dengan cara mengajarkan pembelajaran membaca permulaan di lokasi tempat pengabdian yang dipilih.Memberikan materi pembelajaran membaca permulaan dengan menggunakan modul yang telah kami persiapkan kepada para peserta didik di MI Al-Hikmah kelas 1.

Target yang dicapai dalam program pengabdian kepada masyarakat "UpayaMeningkatkan Kemampuan Membaca Permulaan Kelas 1 SD/MI dengan Metode Iqro di Madrasah Ibtidaiyah AL Hikmah Purwodadi Belitang Mulya Oku Timur"yang dilaksanakan oleh Dosen Jurusan Pendidikan Guru Madrasah Ibtidaiyah adalah:

1. Supaya siswa Mlterbantu untuk mempelajari mapel bahasa Indonesia pada aspek membaca.

2. Memanfaatkan modul yang kami persiapan untuk menunjang siswa Ml untuk kemampuan membaca permulaan, agar siswa cepat bisa membaca dengan baik dan lancar.

3. Kegiatan ini dilakukan untuk membantu guru untuk mengajarkan membaca permulaan di MI kelas 1.

Luaran yang dicapai dalam Program Pengabdian kepada masyarakat "UpayaMeningkatkan Kemampuan Membaca Permulaan Kelas $1 \mathrm{SD} / \mathrm{MI}$ Dengan Metode Iqro di Madrasah Ibtidaiyah Al Hikmah Purwodadi Belitang Mulya Oku Timur" oleh Dosen Jurusan Pendidikan Guru Madrasah Ibtidaiyah adalah:

1. Terciptanya kesadaran untuk lebih semangat belajar membaca permulaan kepada siswa MI.

2. Terbinanya para siswa untuk meningkatkan kemampuan membaca permulaan di MI

3. Tumbuhnya motivasi kepada siswa untuk membaca permulaan sehingga dapat membaca dengan baik dan lancar.

\section{HASIL DAN DISKUSI}

Kegiatan pengabdian kepada masyarakat ini dilakukan dengan cara wawancara, praktik, tanya jawab dan pengamatanlangsung selama kegiatan berlangsung. Kegiatan ini dilaksanakan di Madrasah Ibtidaiyah Al-Hikmah Purwodadi, kecamatan Belitang Mulya OKU Timur. Kegiatan pengabdian masyarakat ini memberikan hasil sebagai berikut:

1. Meningkatnya minat baca pada siswa siswi MI Al Hikmah Purwodadi.

2. Meningkatnya pengetahuan dan pemahaman siswa kelas $1 \mathrm{MI}$ Al-Hikmah Purwodadi dalam membaca.

3. Meningkatnya keterampilan membaca pada siswa kelas $1 \mathrm{MI}$ Al-Hikmah Purwodadi.

Adapun faktor pendukung dan penghambat dalam pelaksanaan pengabdian pada masyarakat ini. Ada beberapa faktor yang mendukung terlaksananya kegiatan pengabdian pada masyarakat ini adalah besarnya minat dan antusiasme siswa siswi selama kegiatan, sehingga kegiatan berlangsung 
dengan lancar dan efektif. Sedangkan faktor penghambatnya adalah keterbataasan waktu pada pelaksanaan pengabdian tersebut yakni praktek dalam kelas dengan waktu yang telah ditentukan dari sekolah.

\section{PEMBAHASAN}

Secara garis besar cakupan hasil dari kegiatan pengabdian ini adalah sebagai berikut:

1. Tujuan pengabdian

2. Target materi untuk metode lqra

3. Kemampuan Siswa untuk membaca permulaan

Tingkat ketercapaian pengabdian ini secara umum sudah baik tetapi dengan terbatasnya waktu membuat tidak semua materi pada buku metede lqra tidak tersampaikan dengan detail, namun jika dilihat dari hasil pengabdian maka dapat disimpulkan tujuan dari kegiatan dapat tercapai. Ketercapaian target materi pada kegiatan pengabdian ini terhitung baik, karena materi sudah dapat disampaikan secara keseluruhan. Kemampuan siswa untuk membaca permulaan mulai terlihat dengan baik karena latar belakang siswa yang lebih banyak ngaji di TPA dibandingkan siswa yang lulusan TK, sehingga siswa lebih cepat paham dengan bantuan huruh hijaiyah yang sering dipelajari pada saat mengaji.

Di Mi Al-Hikmah Purwodadi kegiatan pembelajaran membaca permulaannya masih menggunakan cara manual yaitu dengan cara mengeja huruf demi huruf sehingga siswa lebih lama untuk bisa lanncar mebaca. Siswa kelas $1 \mathrm{Mi}$ al-Hikmah Purwodadi berjumlah 16 siswa yang terdiri dari 4 perempuan dan 12 laki-laki. Pada saat pelajaran membaca siswa yang perempuan lebih malu diminta untuk membaca karena belum begitu lancar menghafal huruf abjad, begitupun dengan siswa lakilakinya masih ada beberapa yang sudah lancar. Keadaan ini, bisa disebut kurang memenuhi ekspektasi diawal. Namun tidak mengurangi tujuan dari pada pengabdian ini. Setalah mendapatkan metode pembelajaran membaca dengan metode lqra siswa lebih termotivasi dan lebih bersemangat untuk bisa dan mau membaca

Secara keseluruhan kegiatan pengabdian ini dapat dikatakan berhasil. Keberhasilan ini selain diukur dari beberapa komponen yang telah disebutkan juga dilihat dari kepuasan dan juga permintaan tambahan waktu pengabdian dari kepala sekolah dan guru kelas 1 , serta guru kelasnya meminta untuk diajari untuk memberikan metode lqra yang dilaksanakan kepada siswanya.

\section{SIMPULAN}

Dari kegiatan pengabdian kepada masyarakat dapat disimpulkan bahwa dengan menggunakan metode lqra dapat meningkatkan minat baca pada siswa siswa MI Al-Hikmah Purwodadi, meningkatkan pengetahuan dan pemahaman siswa kelas $1 \mathrm{Mi}$ Al-Hikmah Purwodadi dalam membaca, serta dapat meningkatkan ketrampilan membaca pada siswa kelas $1 \mathrm{Ml}$ Al-Hikmah Purwodadi.

\section{UCAPAN TERIMAKASIH}

Terima kasih yang tak terhingga kepada Ketua STKIP Nurul Huda Sukaraja dan Ketua LPPM STKIP Nurul Huda Sukaraja yang telah memberikan kesempatan kepada kami dalam melaksanakan pengabdian dengan menerbitkan nomor kontrak pengabdian 017/STKIP-NH/LPPM/XI/2018, sebagai salah satu bentuk Tri darma perguruan tinggi di STKIP Nurul Huda Sukaraja, terima kasih juga kepada anggota Jurnal Indonesia Mengabdi STKIP Nurul Huda Sukaraja, kepala sekolah Mi AI-Hikmah Purwodadi serta dewan guru terutama guru kelas $1 \mathrm{Mi}$ Al-Hikmah Purwodai yang telah membantu mewujudkan kegiatan pengabdian ini dengan mengizinkan kami melaksankan kegiatan di MI AlHikmah Purwodadi dan kepada semua dosen di lingkungan STKIP Nurul Huda terima kasih atas support dan bantuan moril sehingga pengabdian ini bisa berjalan dengan baik dan lancar. 


\section{DAFTAR PUSTAKA}

Hasanudin, C. (2016). Pembelajaran Membaca Permulaan dengan Menggunakan Media Aplikasi Bamboomedia Bmgames Apps Pintar Membaca sebagai Upaya Pembentukan Karakter Siswa Sd Menghadapi MEA. PEDAGOGIA: Jurnal Pendidikan, 5(1), 1-12

Himmah, Irliana Faiqotul. (2016). Penerapan Metode Iqro' Pada Pembelajaran Calistung Warga Belajar Keaksaraan Fungsional Dasar Merpati. Jurnal Pancaran 5(4): 201-212.

Laely, Khusnul. (2013). Kemampuan Membaca Permulaan Melalui Penerapan Media Kartu Gambar. Jurnal Pendidikan Usia Dini 7(2): 301-320.

Misdar. (2013). Meningkatkan Kemampuan Membaca Permulaan Melalui Media Kartu Kata Bagi Anak Lambat Belajar. Jurnal Ilmiah pendidikan Khusus 1(1): 502-514.

Slamet, St. Y. (2008). Dasar-Dasar Pembelajaran Bahasa dan Sastra di Kelas Rendah. UNS Press. Surakarta.

Susanto, Ahmad. (2011). Perkembangan Anak Usia Dini. Kencana Prenada Media Group. Jakarta.

Tarigan, Henry Guntur. (2008). MembacaSebagai Suatu Keterampilan Berbahasa. Bumi Angkasa. Bandung. 